\title{
Kabalat Shabat em Nahalat Zion (Jerusalém)
}

Tila Amarante Cohen *

O aroma

fresco,

da verbena,

da citronela,

das folhas

de luísa,

de hortelã.

$\mathrm{O}$ ar

perfumado,

que eleva

o espírito

e introduz

a santidade

do shabat.

\section{As faces}

mouriscas,

do Oriente;

as barbas

negras,

os olhos

que se fecham

ao aspirar

o rapé.

Os sons

ásperos,

doces

e guturais

do hebraico,

do aramaico,

que cantam

e repetem

a tradição,

a dança,

a fé,

a Torá!

* Tila Amarante Cohen é Professora Titular da Universidade Federal de Minas Gerais e coordenadora do Programa de Pós-Graduação em Letras: Estudos Lingüísticos da Faculdade de Letras da UFMG. 